\title{
2 \\ Vivisection, Virtue, and the Law in the Nineteenth Century
}

The history of vivisection is inseparable from that of medical science. Without animal experimentation, the course of medicine would have been radically different (one can admit as much without making any presumption about the validity of animal models). Since the nineteenth century, laboratory experimentation has become the gold standard of academic medicine, shaping not only its approach to solving problems, but also the moral conduct and education of doctors. To experimentalists, it was axiomatic that medical science must be objective, rational, and dispassionate: if its advancement required the infliction of pain on laboratory animals, then it was unprofessional, even unethical, to allow squeamishness or sentiment to get in the way. Thus there arose a tension in medicine between the scientific spirit of cool indifference to suffering and the clinical tradition of compassion and caring. When the Continental fashion for vivisection first touched Britain in the 1820s, many doctors chose to distance themselves from it for the sake of their reputation, and the few who did undertake it felt the need to defend a choice that seemed at odds with the ethos of their profession.

Though 'anti-vivisection' became, in the course of the nineteenth century, so familiar a term of self-description that it would be obtuse to call organized opposition to animal experimentation by any other 
name, its use has perhaps distorted the way that both the individuals and organizations involved have been understood, implying as it does protest, negativity and perhaps even rejection of progress - a campaign by some out of step luddites and radicals to halt the march of science, or to make a heavy-handed moral point about the abuse of power within society. It would, however, be no less apt to view vivisectionists as the protesters and their opponents as the conservative majority. There was never a time in Britain when there were more people active in support of vivisection than against it, and in the nineteenth century the antis raised petitions with hundreds of thousands of signatures, more than for any other cause of the time. A key question for the historian is why, considering the level of popular support and money at their disposal, anti-vivisectionists made so little progress in curbing, still less ending, experiments on animals. The remarkable success of experimentalists in winning over the government, legislature, and universities, and in carrying through their objectives in a nation of reputed animal lovers, which proved critical in shaping the course of medical science and ethics, also calls for an explanation.

During the nineteenth century, the anti-cruelty lobby went from being largely unaware of vivisection to passionately opposing it, largely due to a few high-profile incidents. By the century's end, antivivisection had become a humanitarian cause celebre, a mainstream issue with great public support and many societies dedicated to it, despite vivisection being responsible for only a tiny fraction of the vast amount of suffering inflicted on animals by human hands. Vivisection was seen as different from other forms of cruelty, such as the mistreatment of farm and draught animals, partly because those responsible were linked with the healing and academic professions, whose morality was supposed to be beyond reproach, and also because it had implications beyond animal welfare: for the way society made ethical choices, for how science should be conducted, and for how humans saw themselves in relation to the rest of creation. Because of the multiplicity of moral problems that vivisection raised, the anti-vivisection movement attracted people with all sorts of religious, political, and social principles to defend, and with such disparate views that, according to Vyvyan, anti-vivisection was often the only thing they had in common. 


\section{Legislating Against Cruelty}

The resurgence of interest in animal protection in the 1970s prompted historians to revisit its history, and pioneering studies such as those of Richard French set early-nineteenth century anxieties over cruelty to animals in the context of post-Revolutionary concerns about the damage that a culture of violence might do to human society. ${ }^{1}$ According to French and to Anita Guerrini, calls for laws to protect animals were primarily a form of social self-defence, requiring the government, with the cooperation of middle class activists, to legislate to control the violent impulses of an underclass who lacked the wherewithal to regulate themselves, and who, if permitted to acquire a taste for blood, might soon become ungovernable. At the other end of the spectrum of anthropocentric concern for mistreated animals there were radicals, particularly feminists and socialists, who saw animals as surrogates for disempowered humans. ${ }^{2}$ If one adds to these British doctors who resented the introduction of novel, Continental experimental methods that challenged their tradition of observational bedside medicine, it can be seen that there were plenty of people calling for a ban on vivisection who were concerned with their own interests rather than those of animals.

Walter Bagehot famously said that one cannot make men good by act of parliament, but early-nineteenth century anti-cruelty legislation was an attempt to do just that. The sight of bloodthirsty crowds at cock-fights and bull-baitings was especially disturbing for an urban bourgeoisie still unsettled by the French Revolution. If casual cruelty to animals led to, or at least stoked a propensity for, violence against humans (a link, incidentally, that is now well established ${ }^{3}$ ), then its elimination would be in society's interest. Parliament, however, was slow to act, partly because its members could not decide if blood sports were incitements to cruelty or safe outlets for high spirits. ${ }^{4}$

Attempts by private members to put legislation through parliament finally met with success in Richard Martin's (1754-1834) Cruel and Improper Treatment of Cattle Act (3 George IV. c. 71), which became law in 1822. Martin - an Irish politician, duelist and gambler on whom George IV bestowed the nickname 'Humanity Dick'—had been elected to the UK parliament at the time of the Act of Union, but his bill 
was of little interest to most of its members, who greeted it with mocking laughter. ${ }^{5}$ That there was enough support for it to be passed at all was mostly due to London's changing demographic: in the crowded capital, the well to do could not avoid witnessing the brutal treatment of draught animals and livestock. Prior to Martin's Act, it had been against the law to harm an animal only if it were someone else's property, an offence equivalent to criminal damage, but the Act criminalized cruelty to one's own 'cattle' (though not domestic animals). Since there was no funding to enforce it, the law's effectiveness depended upon private citizens being willing to report acts of cruelty and prosecute those responsible in the magistrates' courts. ${ }^{6}$

Voluntary associations such as the Society for the Prevention of Cruelty to Animals (SPCA), founded in 1824, were set up to help gather evidence and bring prosecutions. ${ }^{7}$ Their founders hoped this would improve the 'moral temper' of the populus, ${ }^{8}$ but the legal requirement for an offender to have acted 'wantonly and cruelly' made convictions for cruelty rare, since any rational act, however heartless, was not 'wanton' in a court of law. For example, a man who whipped a goat pulling a cart was found not guilty because he said he had beaten the animal in order 'to make it go'.' A far-reaching consequence of this, and subsequent, anti-cruelty legislation was that people focused on staying within the law rather than doing what was right, turning cruelty from a moral to a legal problem. The best that anti-cruelty societies could hope for was that fear of prosecution would make the urban poor, who they considered to be the chief offenders, take greater responsibility for their own actions, and thus 'compel them to think and act like those of a superior class'. ${ }^{10}$

Martin's Act did not mention vivisection, probably because he was unaware of it. It was a sign of their rarity in Britain that even someone as concerned as he about animal welfare does not seem to have known about experiments on animals until 1824, when the French physiologist François Magendie (1783-1855) gave a widely-reported demonstration at London's Windmill Street anatomy school. ${ }^{11}$ The published accounts of Magendie's experiment, in which he nailed a greyhound to the dissecting-table before cutting it open, provoked a vociferous anti-French outcry that marked the start of the organized anti-vivisection movement 
in Britain. ${ }^{12}$ Thereafter, Martin spoke out against Magendie in particular and vivisection in general, but his own law was powerless to stop it because scientific experiments were performed in a deliberate, calculated manner and not 'wantonly', and so could not, by definition, be cruel under the law. ${ }^{13}$ The need to show they were compliant with anti-cruelty law inclined future experimenters to favour utilitarian arguments, because anticipated benefits to human health provided a clear, rational justification for their work.

\section{Medical Opposition to Vivisection}

At the time of Magendie's arrival in England, vivisection was 'proverbially rare. ${ }^{14}$ It has been estimated that in the 1820 s fewer than a thousand experiments on animals were performed each year in the whole of the British Empire, and English medical men were said to have a particular 'horror' of them. ${ }^{15}$ At this time, the medical 'profession' was a loosely defined group with no common licensing or regulatory body, so there was no 'official' position on animal experimentation, but groups of practitioners, concerned that physiological experiments would give medicine a 'bad name', signed up to anti-vivisection testimonials. ${ }^{16}$

Particularly worrying for medics was the rumour that Magendie found experimentation pleasurable, a shocking claim, though not an unreasonable one, as according to a medical eyewitness who attended his demonstrations in Paris: '...he really likes his business... when loud screams are uttered, he sometimes laughs outright'. ${ }^{17}$ Magendie's supporters seem to have been aware of the damage that a reputation for callousness could do to his medical career, since they published a testimonial to his kindly bedside manner, presumably aimed at reassuring patients and others that his heartlessness in the laboratory did not extend into his clinical practice. ${ }^{18}$

In the wake of the Magendie scandal, the secretary of the SPCA seized the opportunity to solicit the support of prominent medical men for 'a board ... of the profession, to whom all proposed experiments must be submitted'. ${ }^{19}$ The medical dignitaries to whom he wrote all declared themselves against unrestrained vivisection, and a selection 
of their replies, calling for curbs on animal experiments, was published in the national press. ${ }^{20}$ The SPCA wanted a panel of distinguished doctors to decide what experiments should be permitted, but to Lewis Gompertz (1783/1784-1861), who founded the rival Animals' Friend Society (AFS) in 1833 after resigning from the SPCA, this was unacceptable. Gompertz, who rejected scientific 'necessity' as a justification for cruelty, and wanted the wording of Martin's Act changed to read 'wantonly or cruelly', had no faith in medical self-regulation. He offered a cash reward for evidence leading to the conviction of surgeons or medical students who 'cut up Dumb Animals Alive', ${ }^{21}$ though it was never claimed because, as Thomas Wakley (1795-1862), the outspoken editor of the medical journal the Lancet, complacently pointed out, anticruelty law did not apply to medical experiments. ${ }^{22}$ In a misguided attempt to remedy this, the AFS campaigned for, and got, an extension of Martin's law to include the domestic animals experimenters usually used, but this made no difference as experiments on them would still not be judged 'wanton' by a magistrate. ${ }^{23}$

\section{The Character of the Vivisector}

One London medical journal accused doctors who opposed vivisection of trying to 'curry favour' with patients, which suggests that patients were known to prefer doctors who were not vivisectionists. ${ }^{24}$ Some people were afraid that the vivisectors' real objective was to experiment on humans, and as charity patients were thought to be their most likely victims, anti-vivisection became a popular cause in poor districts of London. ${ }^{25}$ Paying patients had less reason to fear being used as experimental material, but they tended, as patients still do, to choose their doctor on the basis of personal attributes such as compassion, kindness and humanity rather than on purely technical ability, which made anti-vivisection a pragmatic position for medics in private practice to adopt. $^{26}$

There was a longstanding, though apocryphal, tradition that anatomists and butchers were banned from serving on coroners' juries because their trades destroyed their moral competence, and vivisection 
was presumed to have a similar effect, especially on impressionable young students. ${ }^{27}$ According to the Irish physician and naturalist James Lawson Drummond (1783-1853), 'little was to be expected' of medical students who became habituated to vivisection, a concern echoed by the SPCA's president Lord Carnarvon, who claimed that it was because they knew that the vivisector's 'feelings of compassion for suffering [could become] entirely obliterated', that the majority of medics wanted it restricted by law. ${ }^{28}$

There is no official record of how many experiments on animals were performed in Britain before the 1876 Vivisection Act, but few were reported in medical journals (most of the experiments published in British journals were performed in France or Germany) and they do seem to have been truly rare. Concerns within the medical profession were probably instrumental in keeping them so, though the few British doctors who did vivisect met with less criticism in the press than their Continental counterparts, partly because there was an element of nationalism behind protests against French physiologists, but also because the English tended not to carry on their work in public.

Opponents of Continental style vivisection demonstrations feared that these open displays of cruelty by professional people would lead to a general moral decline. ${ }^{29}$ A well-known account by French physiologist Claude Bernard (1813-1878) of a Quaker who berated Magendie in his own laboratory provides a concise summary of public concerns:

Thou performest experiments on living animals. I come to thee to demand of thee by what right thou actest thus and to tell thee that thou must desist from these experiments, because thou hast not the right to cause animals to die or make them suffer, and because thou settest in this way a bad example and also accustomest thyself to cruelty. ${ }^{30}$

A review of the case against vivisection by the AFS in 1833 grouped objections to it under five headings: to inflict pain on animals was a moral failing, it engendered public animosity against scientists, encouraged cruelty towards humans, distracted charitable efforts away from human suffering, and offended God. ${ }^{31}$ Significantly, even this most committed of anti-vivisection groups relied on anthropocentric 
arguments: the suffering experienced by animals and their rights or interests were of lesser importance than the effects of vivisection on the experimenter and on society. ${ }^{32}$

British medical practitioners in search of moral guidelines had no governing body to turn to and no written code of conduct to help them; the word 'ethics' was seldom mentioned in medical writing, and there was no specific legislation governing medical practice until the Medical Act of 1858. There was, however, a widely-accepted code of etiquette and personal morality, which, though it included some rules of conduct specific to doctors, such as not stealing a colleague's patients, was largely that of their social group. A medical man was expected to be, or at least act like, a gentleman, a class whose 'honour and humanity are unimpeachable'. ${ }^{33}$ For those to whom gentility did not come by birth or upbringing, guidebooks known as gentlemen's manuals provided instruction on correct manners and behaviour: the proper treatment of animals was neither cruel and heartless nor overly emotional, since brutality on the one hand and sentimentality on the other fell short of gentlemanly standards. ${ }^{34}$

I have argued elsewhere that the ideal of gentlemanly medical conduct was, in modern terms, an expression of virtue ethics, a system first described in Aristotle's Nicomachean Ethics and distinguished by its focus on motives and character rather than actions. ${ }^{35}$ In the eighteenth century, in what has been termed 'the decline of virtue', character-based ethics began to lose ground to utilitarianism and deontology, but medicine still retained an old-fashioned attachment to the virtues and a strong emphasis on the good character of its practitioners. ${ }^{36}$ For example, in the Fortnightly Review of (1882), the physician William Benjamin Carpenter (1813-1885) wrote that the morality of a pain-giving act lay not in the act itself (deontological ethics), nor in its result (utilitarianism), but in the motive for the act, a test that was also applied to vivisection. ${ }^{37}$

How patients and professionals interpreted the motives behind vivisection was therefore crucial in shaping their response to it. Not a few thought that vivisectors must be callous-like Magendie, they were thought to ignore, or even laugh at, animals' screams - a particularly damning charge for those who treated patients. ${ }^{38}$ As long ago as 1758, Samuel Johnson (1709-1784) had fulminated against vivisectionists 
in his periodical the Idler, writing that '[i]t is time that a universal resentment should arise against these horrid operations, which tend to harden the heart and make the physician more dreadful than the gout or the stone. ${ }^{39}$ A century later, a similar sentiment was being quoted with approval by the British Medical Journal: 'Let there be no mistake about it: the man who habituates himself to the shedding of blood, and who is insensible to the sufferings of animals, is led on into the path of baseness' ${ }^{40}$

Virtue ethics did not, however, offer a decisive argument against vivisection. To shun it, as the controversial and outspoken anatomist Robert Knox (1793-1862) did, might be taken as a sign of 'humanity', but others claimed that vivisectionists were prompted by worthy motives such as the desire to alleviate human suffering and to acquire knowledge. ${ }^{41}$ The challenge lay in deciding which personal qualities to favour: what Charles Darwin (1809-1882) called the 'virtue' of 'humanity to the lower animals', or the laudable wish to advance medical learning. ${ }^{42}$ Virtue ethics did not offer a glib solution: the ideal medical character was a balanced one, and it was 'proverbial' that medics ought to be neither unduly sentimental, lest squeamishness made them shrink from their work in order to spare their own feelings, nor so insensitive that they became callous. ${ }^{43}$

A degree of fortitude and resolve was expected of all well-bred men, and anti-vivisectionists and others who were thought to be deficient in these manly, Christian virtues were criticised as 'effeminate'. As some seventy percent of anti-vivisectionists were women, some of whom used the abuse of animals as a metaphor for their own perceived vulnerability, the cause itself came to be seen as feminine, and men who took it up were subject to accusations of unmanliness. ${ }^{44}$ One critic called anti-vivisectionists 'old ladies of both sexes', the implication being that their opinions were formed by emotion rather than intellect and were therefore out of place in a scientific debate. ${ }^{45}$ Experimenters faced the opposite criticism, that they were so dispassionate as to be wanting in normal human feeling. That medical practitioners who made public statements about vivisection predominantly opposed it, while those who supported it maintained a low profile, suggests that sensitivity was a quality more attractive to potential patients than fortitude and commitment to medical science. 


\section{Bad Science}

The often-asked question of why most people who objected to vivisection nevertheless ate meat (or wore leather, or hunted) shows that experimenting on animals was seen as a separate moral issue from eating them, wearing them or chasing them, a distinction sometimes lost on the more logically minded: George Bernard Shaw (1856-1950) was shocked to find himself sharing a platform with hunters and fur-wearers when he spoke at an anti-vivisection meeting. ${ }^{46}$ From a historical perspective we are not concerned with whether theirs was a coherent or defensible position, but with why they thought as they did. One explanation of why vivisection seemed to be of a different order from other cruelties was that those who performed it were neither the ignorant poor nor the feckless rich but scientists and doctors, precisely the sort of educated, professional people from whom society expected exemplary standards of conduct. ${ }^{47}$

Nineteenth century science was as much an attitude of mind as a field of study, an objective discipline where feelings did not intrude, and whose practitioners cultivated detachment and self-control. But their duty to suppress any feelings of compassion whilst working was problematic: quite apart from the difficulty of arguing that it was virtuous to suppress a virtue, how was an individual who steeled himself to perform vivisection for altruistic motives to be distinguished from someone so morally indifferent as to give no thought to the suffering he was about to inflict? According to the President of the British Association for the Advancement of Science, an organization whose remit was to defend experimentation, the fact that vivisectionists were 'men of science' meant that, unlike 'persons in the lower order', there was no question of their being unthinkingly cruel, not least because their experiments were too 'tedious and toilsome' to be performed unthinkingly. ${ }^{48}$

One could, however, be heartless without being reckless, and the argument that vivisectionists could control their finer feelings at will did not convince even some doctors, who thought that anyone prepared to inflict pain on helpless animals must be seriously lacking in emotional sympathy. Dr Robert Hull, writing against vivisection in the London Medical Gazette, agreed with the surgeon John Abernethy (1764-1831) 
that any doctor who vivisected was unfit to attend a family, and the Protestant Magazine concurred, printing a 'caution to parents' advising them to shun the services of any practitioner who carried out vivisection. ${ }^{49}$ This was not a 'slippery slope' argument, since it presumed that vivisectionists were already deficient in empathy: as Immanuel Kant had written, 'we can judge the heart of a man by his treatment of animals'. ${ }^{50}$

The controversy over vivisection shows many parallels with that over human cadaveric dissection that took place in the early 1830s, to the extent that the arguments for and against both were regarded as interchangeable (the public also assumed that anatomists were all vivisectionists, despite their protests to the contrary). ${ }^{51}$ Both practices were criticised not because of the suffering they caused but because of the supposed cold-heartedness and self-indulgence of the perpetrators, and both became the subject of public scandals that gave rise to regulatory legislation: the much-publicized murders for dissection in Edinburgh and London between 1829 and 1831 led to the 1832 Anatomy Act that legalized pauper dissection, while the shocking experiments performed by the French physiologist Éugène Magnan on a visit to Britain in 1874 led to the introduction of licensing for vivisectionists through the 1876 Cruelty to Animals Act. Vivisectionists and anatomists alike defended themselves with utilitarian arguments (vivisecting animals and dissecting cadavers were necessary to train doctors and develop new treatments), and also tried to show that their motives were virtuous. The 'heroic anatomist', who set aside any personal feelings and stoically endured the horrors of the dissecting-room, was a prototype of the 'imperturbable scientist' who when experimenting on animals in the laboratory was 'callous for the sake of what he deemed the greater compassion. ${ }^{52}$

Believing that vivisection might be performed by virtuous people still did not make it good science. Experimenters claimed their work would 'place the art of healing upon a firmer basis', and they certainly obtained objective, quantitative data from animals that could not easily have been got from humans, but there were plenty of methodological objections. ${ }^{53}$ A somewhat facile criticism, dating back to the seventeenth century, was that normal function could not reliably be investigated in living animals because their responses under vivisection did not represent a normal state (facile because no interventional experiment can ever study 
a truly 'normal' state). In the nineteenth century, however, it was subtly modified: animal experiments were bad science because they were a crude and clumsy attempt to wrest Nature's secrets from her by force, rather than through skillful philosophical enquiry, and so they reflected badly on the judgement and finesse of those who resorted to them. ${ }^{54}$ Drummond compared vivisection to judicial torture in that it both yielded untrustworthy information and discredited the inquirer, and Karl Marx thought it of doubtful value, and an affront to 'humanity'. ${ }^{5}$

Another common methodological criticism was that animal physiology differed so greatly from the human that results could not be extrapolated. ${ }^{56}$ In theory, this was difficult for experimenters to counter because if animals were physiologically similar to humans, they likely felt as humans did and so it was cruel to make them suffer, while if they lacked human sensitivity to pain, they were significantly different from us physiologically: so an experiment was 'criminal' if an animals' physiology was like ours and 'objectless' if it was not. ${ }^{57}$ Though this might seem a powerful argument against experimentation, it was unusual for nineteenth-century vivisectors to concern themselves with animal pain at all: like Darwin, they could accept that ' $t$ the lower animals, like man, manifestly feel pleasure and pain, happiness and misery' and still consider vivisection justifiable. ${ }^{58}$ We will consider in the following chapter whether the categorical difference between humans and animals that left the latter vulnerable to experiment was primarily spiritual rather than physiological.

\section{Necessity and Humanity}

Though British medical practitioners generally disliked the showy displays by Continental physiologists that had 'drawn odium' upon their profession, they were more sympathetic to experimentation done by their own countrymen, provided it was 'necessary' to medical progress: William Harvey's (1578-1657) work on the circulation of blood and John Hunter's (1728-1793) on aneurysms were the most often cited examples. Writing in the 1860s, the physician and author Andrew Wynter (1819-1876) declared that Hunter's work alone had been worth 'the destruction of a whole 
hecatomb of dogs', and though few vivisectionists made discoveries of the same magnitude as Hunter's, they all anticipated benefits to humankind and used this to justify their work..$^{59}$ Their self-assessment of utility was, of course, subjective: in his monograph Vivisection Investigated and Vindicated, the English physician George Etherington described among the animal experiments he thought medically important one in which it was shown that creosote, when injected into dogs, acted as a poison, precisely the kind of obvious but apparently pointless result that opponents thought constituted a strong argument against such experiments. ${ }^{60}$

In despair of ever bringing a successful prosecution against a vivisectionist, Gompertz complained that their being allowed to justify their own experiments on the basis of predicted benefits rendered the law 'nugatory'. Naturally, everyone anticipated that their own work would yield vital results, and so 'necessity' had become 'the cheat of humanity' ${ }^{61}$ Even Etherington agreed that the law was rendered powerless by the stipulation that the offender must act 'wantonly': 'the worst moral character, never performs an act without thinking upon and having a motive in performing it... ${ }^{62}$ Throughout the nineteenth century, anti-cruelty groups such as the London Anti-Vivisection Society would continue to complain that medical experiments were being performed 'needlessly, and therefore cruelly', but there was no prospect of a successful prosecution as long as the experimenters themselves were the arbiters of necessity. ${ }^{63}$

British vivisectionists were, however, prepared to accept that many Continental experiments were unnecessary, and they criticized the French, in particular, for an excess of speculative studies and public demonstrations. The relatively few British doctors who did vivisect-most notably Marshall Hall (1790-1857), James Blundell (1791-1878), James Hope (1801-1841) and Charles J.B. Williams (1805-1889)—were prudent and discrete, working privately, publishing in professional journals, and following prearranged lines of investigation. Overall, they were successful in avoiding public scrutiny. Hall, for example, repeated some of Magendie's experiments in the 1820 s, including one in which he opened the chest of a dog and then made him vomit, whereon, according to Hall's own account, 'a portion of lung was driven through the thoracic opening with violence and a 
sort of explosion'. ${ }^{64}$ Though he was criticized in the medical press for this work, there was no public outcry, probably because lay people were simply unaware of it. ${ }^{65}$ Shortly afterwards, Hall published his own 'objective' criteria for deciding whether experiments on animals were justified: the information sought must not be obtainable by observation alone, the experiment must have a distinct and definite object, it must not be a repeat, it must cause the least possible suffering to the least sentient animal, and must be properly witnessed and recorded. ${ }^{66}$ Though they made little impact at the time, his rules would influence the drafting of the Antivivisection Act 40 years later.

The stimulus for legislation, when it came, was not the protests of anti-cruelty campaigners, but the continued animus towards French physiologists on the part of British doctors. When Éugène Magnan visited London in 1874, his medical audience, led by Thomas Jolliffe Tufnell (1819-1885), the President of the Irish College of Surgeons, intervened to stop a particularly unpleasant experiment. ${ }^{67}$ Magnan promptly returned to France, forestalling an attempt by the now Royal Society for the Prevention of Cruelty to Animals to prosecute him, but, while the British organisers of his demonstration were acquitted of any wrongdoing, the magistrates made it clear what they thought by refusing to award the defendants' costs. ${ }^{68}$ This was the closest a vivisectionist in Britain would ever come to being convicted. The case, along with the publication in 1873 of John Burdon-Sanderson's (1828-1905) Handbook for the Physiological Laboratory, a vade mecum for the 'beginner' that made scant reference to anaesthesia, raised such concerns that continental-style vivisection might become acceptable in Britain that in 1875 the government set up a Royal Commission on the matter, the result of which would be the 1876 Cruelty to Animals Act. ${ }^{69}$

\section{The Vivisection Act and the Victoria Street Society}

The 1876 Act (39 and 40 Vict. c. 77), known as the Vivisection Act, mandated that vivisection be performed only for an original, useful purpose. This put an end to the sort of public demonstrations that 
Queen Victoria and many of her subjects so disliked, but left open the private use of animals for medical research and teaching. ${ }^{70}$ The word 'wantonly' was dropped from the definition of cruelty but as, in the expert opinion of Mr Justice Day (Sir John Day, 1826-1908, a judge well known for sentencing felons to flogging), 'cruelty must be something which cannot be justified', the legal requirements for a conviction remained substantially unchanged. ${ }^{71}$ Ironically, it was said that the Royal Commission was convinced of the need for regulation not by anti-vivisectionists, but by the testimony of experts such as the German bacteriologist Emanuel Klein (1844-1925), whose candid admission that he used anaesthesia only for his own convenience-to make the animals easier to handle-spoke volumes about the difference in outlook between scientists and the public:

When you say that you use them [anaesthetics] for convenience sake, do you mean that you have no regard at all for the sufferings of the animals?

No regard at all.

You are prepared to establish that as a principle of which you approve?

I think with regard to an experimenter, a man who conducts special research, he has no time, so to speak, for thinking what the animal will feel or suffer. ${ }^{72}$

Like the Anatomy Act, the Vivisection Act was permissive rather than regulatory. It required all vivisectionists to hold a license but these were liberally bestowed: by 1891, 676 people had been granted one, a large proportion of whom were given 'special' certificates dispensing them from the need to use anesthesia. To acquire an ordinary license, one needed the signatures of two referees who were professors of physiology, medicine, anatomy, or a related discipline; this kept animal experiments 'in the family', so to speak-most licensees worked in the 'golden triangle' of London, Oxford and Cambridge, and enjoyed the support of the universities and medical royal colleges-as well as giving recognition and authority to the new discipline of experimental physiology, whose professional body, the Physiological Society, was founded in the same year the Vivisection Act became law. ${ }^{73}$ 
The surviving correspondence from the London-based Association for the Advancement of Medical Research, which advised the government on licensing, makes no mention of a licence application being refused, and it is quite possible that none ever was: in 1954, when the Home Secretary was asked how many applications had been turned down since 1876, he told the Commons the information was 'not available'. ${ }^{74}$ There was no successful prosecution during the 110 years the Act remained in force. ${ }^{75}$

Medical practitioners opposed to vivisection, some of whom were critical of the Act, were not involved in the licensing process, and ordinary doctors were said to be 'afraid' to speak out because the system was now overseen by the leaders of their profession. ${ }^{76}$ The Act also excluded the public from any involvement in decision making, and made it difficult for them to find out where experiments were taking place, as the licensees' names and addresses were not published. The reason for keeping their identities and locations secret was not fear that they would be intimidated (direct action against vivisectionists was unheard of), but concern that the information might deter patients and donors, and encourage unwelcome efforts by members of the public to gain admittance to demonstrations. ${ }^{77}$

It would be difficult to overestimate the importance of the rise of experimental physiology following the Vivisection Act in shaping the narrative of 'modern medicine', of which Claude Bernard was, in the 1930s, already being called the 'father'. Bernard's influence on George Hoggan (1837-1891), an English doctor who briefly worked in his laboratory, would, however, give life to a very different project. In 1875, Hoggan published a harrowing account of the sufferings of the dogs that Bernard vivisected, though without mentioning him by name. He concluded: '...having drunk the cup to the dregs, I cry off, and am prepared to see not only science, but even mankind, perish rather than have recourse to such means of saving it' ${ }^{78}$

Hoggan suggested to the Irish writer and social campaigner Frances Power Cobbe (1822-1904) that they form a society to campaign against animal experiments, and in 1875, with the support of Lord Shaftesbury (Anthony Ashley-Cooper, 7th Earl of Shaftesbury, 18011885) and the Archbishop of York, William Thomson (1819-1890), 
they formed the Society for the Protection of Animals Liable to Vivisection, better known as the Victoria Street Society (VSS); in 1897, it would become the National Anti-Vivisection Society (NAVS), with Shaftesbury as its president. The Society's goals included preventing the kind of extreme experiments for which Bernard was notorious from being sanctioned in Britain and trying to get the 1876 Act repealed. ${ }^{79}$ In the opinion of the VSS, the Act had led to more experimentation than if vivisection had remained unlicensed, and allowed experimenters to use their 'professional esprit de corps... to secure for themselves prolonged immunity from state interference with their atrocities'. 80

\section{Horrible, Brutalising, Unchristianlike}

Rather than continuing with futile attempts to prosecute vivisectionists, pragmatic campaigners tried to instil compassion into the young through anti-cruelty clubs such as the Band of Mercy movement. ${ }^{81}$ It is apparent from the voluminous and sometimes tedious polemics published at this time that enthusiasts for, and critics of, vivisection were now relying on very different arguments. For vivisectionists, the justification of their experiments was a utilitarian one, since the predicted benefits to medicine outweighed any suffering, and they saw their opponents, as the ageing Darwin penned to The Times in 1876, as tenderhearted but profoundly ignorant. ${ }^{82}$ For their part, anti-vivisectionists laboured the point that anyone who experimented on living animals was callous and insensitive, character traits typically associated with the unthinking lower classes, and certainly undesirable in a medical practitioner or scientist. By the end of the nineteenth century, the sentiment was common among the public that, as Queen Victoria had put it, animal experimentation was: 'horrible, brutalising, unchristianlike', and 'one of the worst signs of wickedness in human nature'. With its focus on reducing the pain experienced by animals and licensing scientists, the Vivisection Act had done nothing to address fears that vivisection 'saps our moral sense', 'blunts our sympathy', and promotes 'ruthlessness and oppression'. ${ }^{83}$ 
In fact, only a small minority of doctors was ever actually involved with animal experiments, and most preferred to avoid them. Despite their stereotypical portrayal in literature as callous and undisciplined, medical students generally shunned vivisection, and it was little used in British medical schools, where many of the teachers shared anatomist Josef Hyrtl's (1810-1894) view that anyone who could look calmly on vivisection would not make a good physician. ${ }^{84}$ The VSS, claiming that the new cadre of licensed, professional vivisectors would become so indifferent to suffering that experimentation would be 'the simple, natural thing to do to any helpless creature in their hands', stoked fears that it would be extended to human subjects. ${ }^{85}$ Of course, patients were not tied to tables and cut up except in the pages of sensational fiction, but there were other ways of experimenting. The microbiologist Robert Koch (1843-1910) actually did experiment on paupers; Louis Pasteur (1822-1895) proposed experimenting on prisoners, and the dermatologist Jonathan Hutchinson (1828-1913) delayed the treatment of a patient with a painful disease the better to demonstrate the signs to his students, all actions, according to the VSS, to which no vivisectionist could logically object. ${ }^{86}$ Though doctors who vivisected may not have treated patients themselves, they could still set a bad example to those who did: if even the most distinguished scientists, wrote Lewis Carroll (Charles Dodgson, 1832-1898), were careless of the suffering they caused, 'what will be the temper of mind of the ordinary coarse, rough man... of whom the bulk of the medical profession... is made up?' 87

Wary of being thought at best heartless and at worst dangerous, experimental physiologists liked to emphasise that their chosen work was disagreeable to them. According to one sympathetic account, the real sacrifices were being made not by the animals but the experimenters: 'we have heard a considerable number of physiologists declare unanimously, that all vivisection tires them exceedingly; sometimes so shatters them, that it requires all their power of will to carry the process through to the accomplishment of the aim...' ${ }^{88}$ This at least indicates they were aware of the importance of character and sensibility in determining how others judged their actions. From a utilitarian perspective, the case for vivisection would have been stronger 
if, in addition to acquiring knowledge from it, physiologists enjoyed their work rather than enduring it; by stating that they undertook experiments reluctantly and at great emotional cost to themselves, they were defending their personal virtue by taking on the persona of the heroic scientist who suffers emotional difficulty through being obliged to transgress normal moral boundaries for the sake of science.

George Romanes (1848-1894), Darwin's disciple, stressed that students of physiology must be none the less gentlemen because they were men of science, though the attitudes characteristic of genteel conduct could be difficult to square with what went on in the laboratory. ${ }^{89}$ Burdon-Sanderson's private admission that 'emotional and sentimental states' such as sympathy were an experimenter's 'greatest enemies' implies a more heartless attitude than that typically expected of a gentleman, though some physiologists may have thought privately what Queen Victoria’s physician Sir William Gull (1816-1890) declared openly: that gentlemen-scientists were above the law, and that anti-cruelty legislation was 'for the ignorant, and not for the best people in the country..$^{90}$

For the antis, Cobbe memorably asked if:

... advancement of the 'noble science of physiology' is so supreme an object of human effort that the corresponding retreat and disappearance of the sentiments of compassion and sympathy must be accounted as of no consequence in the balance? ${ }^{91}$

How people answered such questions would determine whether they gave their money, and trusted their health, to vivisectionists, and whether they saw the rise of laboratory medicine as a major advance or a wrong turning.

\section{Notes}

1. French, Antivivisection and Medical Science (French 1975).

2. Anita Guerrini, 'Animal experiments and anti-vivisection debates in the 1820s', in C. Knellwolf and J. Goodall (eds.), Frankenstein's 
Science: Experimentation and Discovery in Romantic Culture, 1780-1830 (Aldershot: Ashgate, 2008), 71-86; Coral Lansbury, The Old Brown Dog: Women, Workers, and Vivisection in Edwardian England (Madison, WI: University of Wisconsin Press, 1985); Mary Ann Elston, 'Women and anti-vivisection in Victorian England, 1870-1900', in Rupke, Vivisection in Historical Perspective; Hilda Kean, 'The "smooth, cool men of science:" the feminist and socialist response to vivisection', History Workshop Journal, 40 (1995), 16-38; Hilda Kean, Animal Rights: Social and Political Change since 1800 (London: Reaction, 1998); Ian Miller, 'Necessary torture? Vivisection, suffragette force-feeding, and responses to scientific medicine in Britain c. 1870-1920', Journal of the History of Medicine and Allied Sciences, 64 (2009), 333-372 (Guerrini 2008; Lansbury 1985; Elston 1987; Kean 1995, 1998; Miller 2009).

3. Andrew Linzey (ed.), The Link between Animal Abuse and Human Violence (Brighton: Sussex Academic Press, Linzey 2009) (Linzey 2009).

4. Charles D. Niven, History of the Humane Movement (London: Johnson Publications, 1967), 57-58; Kean, Animal Rights, 33-34 (Niven 1967).

5. Niven, History of the Humane Movement, 61 (1967).

6. Gordon Hughes and Claire Lawson, 'RSPCA and the criminology of social control', Crime, Law and Social Change, 55 (2011), 375-389 (Hughes and Lawson 2011).

7. SPCA, Sixth Report and Proceedings (London: W. Molineux, 1832) (SPCA 1832).

8. Kean, Animal Rights, 36 (1998).

9. Anon., Animals Friend, 7 (1839), 51.

10. 'Society for the prevention of cruelty to animals', Evangelical Magazine and Missionary Chronicle, 2 (1824), 357-358.

11. 'On experiments on living animals', London Medical Gazette, 20 (1837), 804-808.

12. J.M.D. Olmsted, François Magendie: Pioneer in Experimental Physiology and Scientific Medicine in Nineteenth-Century France (New York, NY: Schuman, 1944), 137 (Olmsted 1944).

13. 'Vivisection per se cannot be ranked among acts of cruelty': see, 'The ethics of vivisection', Lancet, 2 (1860), 143-144.

14. George F. Etherington, Vivisection Investigated and Vindicated (Edinburgh: P. Richard, 1842), 17 (Etherington 1842).

15. François Magendie (transl. E. Milligan), An Elementary Compendium of Physiology; for the use of Students (Philadelphia: James Webster, 1824), 261; Etherington, Vivisection Investigated, 80 (Magendie 1824). 
16. 'Physiology', Medico-Chirurgical Review, 3 (1825), 198-200; Etherington, Vivisection Investigated, 111.

17. Olmsted, François Magendie (1994), 221-222 (Olmsted 1944).

18. 'Bills to prevent cruelty to animals', Parliamentary History and Review (1826), 756-775.

19. David Mushet, The Wrongs of the Animal World (London: Hatchard and Son, 1839), 209 (Mushet 1839).

20. 'Society for preventing cruelty to animals', Morning Chronicle, June 1825, 3 (Society for preventing cruelty to animals 1825).

21. Lewis Gompertz, Moral Inquiries on the Situation of Man and Brutes; On the Crime of Committing Cruelty on Brutes, and of Sacrificing Them to the Purposes of Man (Fontwell: Centaur Press, 1992), 147 (Gompertz 1992).

22. J. Chippendale, 'Experiments on animals', Lancet, 1 (1839), 357-358 (Chippendale 1839).

23. 'Amendment of the laws to prevent cruelty to animals', Animals Friend, 2 (1834), 11-15. The bill (5 and 6 William IV. c. 59) was passed with the help of Quaker MP Joseph Pease.

24. 'Physiology', Medico-Chirurgical Review, 3 (1825), 198-200.

25 . 'Correspondence on field sports and surgical experiments on living animals', Animals Friend, 6 (1838), 21.

26. Trevor Stammers, 'The NHS-no place for conscience', Catholic Medical Quarterly, 63 (2013), 12-14 (Stammers 2013).

27. Lloyd G. Stevenson, 'Religious elements in the background of the British anti-vivisection movement', Yale Journal of Biology and Medicine, 29 (1956), 125-157. No such restriction on jurors ever existed: Leigh Hunt, Essays (London: Edward Moxon, 1841), 47-48 (Stevenson 1956; Hunt 1841).

28. James Lawson Drummond, 'On humanity', London Medical Gazette, 24 (1838/1839), 160-163 (Drummond 1838/1839).

29. A.W. Bates, “Indecent and demoralising representations": public anatomy museums in mid-Victorian England', Medical History, 52 (2008), 1-22 (Bates 2008).

30. Quoted in: Mary T. Phillips and Jeri A. Sechzer, Animal Research and Ethical Conflict: An Analysis of the Scientific Literature: 1966-1986 (New York: Springer-Verlag, 1989), 7 (Phillips and Sechzer 1989).

31. Anon. 'Five reasons against cruelty to animals', Animals Friend, 1 (1833), 14 (Anon 1833).

32. Rob Boddice, A History of Attitudes and Behaviours toward Animals in Eighteenth- and Nineteenth-Century Britain: Anthropocentrism and 
the Emergence of Animals (Lampeter: Mellen, 2007); Anita Guerrini, 'Animal experiments' (Boddice 2007).

33. 'Surgical experiments on living animals', Animals Friend, 7 (1839), 61-62.

34. Anon., The Young Gentleman's Book (London: Baldwin and Cradock, 1832), 249.

35. A.W. Bates, 'Vivisection, virtue ethics, and the law in 19th-century Britain', Journal of Animal Ethics, 4 (2014), 30-44 (Bates 2014).

36. Thomas Percival, Medical Ethics, or a Code of Institutions and Precepts Adapted to the Professional Conduct of Physicians and Surgeons (Manchester: S. Russell, 1803) (Percival 1803).

37. William Benjamin Carpenter, 'The ethics of vivisection', Fortnightly Review, 31 (1882), 237-246 (Carpenter 1882).

38. Olmsted, François Magendie (1944), 221-222 (Olmsted 1944).

39. Samuel Johnson, Idler, 17 (1758), 64.

40. Anon., 'Vivisections in France', BMJ, 2 (1863), 215.

41. 'Dr Knox, of Edinburgh', Medical Times, 10 (1844), 245-246; William Hamilton Drummond, The Rights of Animals, and Man's Obligation to treat them with Humanity (London: John Mardon, 1838), 23, 148. (Knox 1844; Drummond 1838).

42. Charles Darwin, The Descent of Man (London: John Murray, 1871), 2 vols, 1, 101 (Darwin 1871).

43. 'Body-snatchers', Church and State Review, July 1862, 87; James A. Steintrager, Cruel Delight: Enlightenment Culture and the Inhuman (Bloomington, IN: Indiana University Press, 2004), 64, 124 (Steintrager 2004).

44. Andreas-Holger Maehle, 'The ethics of experimenting on animal subjects', in Robert B. Baker and Laurence B. McCullough (eds), The Cambridge World History of Medical Ethics (Cambridge, Cambridge University Press, 2014), 552-557 (Maehle 2014).

45. Andrew Wynter, Subtle Brains and Lissom Fingers: Being Some of the Chisel-Marks of Our Industrial and Scientific Progress, and Other Papers (London: Robert Hardwicke, 1863), 66 (Wynter 1863).

46. George Bernard Shaw, Prefaces (London: Constable, 1934), 257 (Shaw 1934).

47. Hayley Rose Glaholt, 'Vivisection as war: the "moral diseases" of animal experimentation and slavery in British Victorian Quaker pacifist ethics', Society and Animals, 20 (2012), 154-172 (Glaholt 2012). 
48. 'The British Association for the Advancement of Science', Medical Times and Gazette, 2 (1863), 258-260.

49. Robert Hull, 'On vivisection', London Medical Gazette, 32 (1842/1843), 864. 'A caution to parents', Protestant Magazine, 6 (1844), 57-58 (Hull 1842/1843).

50. Tom Regan and Peter Singer (eds.), Animal Rights and Human Obligations (Englewood Cliffs, NJ: Prentice-Hall, 1989), 24 (Regan and Singer 1989).

51. Wynter, Subtle Brains, 67 (1863); Brayfytte, 'Experimental physiology: what it is, and what it asks', Animals Guardian, 2 (1891/1892), 39-42.

52. Simon Chaplin, 'The heroic anatomist: dissection and the stoic ideal' (2008), retrieved from http://www.rcpe.ac.uk/library/listen; A.W. Bates, The Anatomy of Robert Knox: Murder, Mad Science and Medical Regulation in Nineteenth-Century Edinburgh (Brighton: Sussex Academic Press, 2010), 21; Boddice, 'Species of compassion' (Bates 2010; Chaplin 2008).

53. 'Vivisection at Alford', Lancet, 2 (1860), 395-396.

54. Rupke, Vivisection in Historical Perspective, 22.

55. Drummond, The Rights of Animals, 145; 'Christianity and its effect upon man's treatment of animals considered', Church of England Magazine, 6 (1839), 294-296; K.F.H. Marx (transl. J. Mackness), The Moral Aspects of Medical Life (London: John Churchill, 1846), 121 (Marx 1846).

56. 'F. Lallemand, Observations pathologiques propres à éclairer plusieurs points de physiologie' (review), London Medical and Physical Journal, 53 (1825), 238-245; Robert Knox, 'Some observations on the structure and physiology of the eye and its appendages', Lancet, 1 (1839), 248-251 (Lallemand 1825; Knox 1839).

57. M. Lordat, Mental dynamics in relation to the science of medicine', Journal of Psychological Medicine and Mental Pathology, 7 (1854), 252263 (Lordat 1854).

58. Regan and Singer, Animal Rights, 27 (1989).

59. Wynter, Subtle Brains, 68 (1863).

60. Etherington, Vivisection Investigated.

61. 'Necessity the cheat of humanity', Animals Friend, 9 (1841), 16.

62. Etherington, Vivisection Investigated, 72.

63. 'Our programme', Animals Guardian, 1 (1890), 2.

64. Marshall Hall, 'On the mechanism of the act of vomiting', Lancet, 2 (1828), 600-602 (Hall 1828). 
65. Diana E. Manuel, 'Marshall Hall (1790-1857): vivisection and the development of experimental physiology', in Rupke, Vivisection in Historical Perspective, 78-104 (Manuel 1990).

66. Marshall Hall, A critical and Experimental Essay on the Circulation of the Blood (London: R.B. Seeley \& W. Burnside, 1831), 2-7 (Hall 1831).

67. 'Prosecution at Norwich', British Medical Journal, 2 (1874), 751-754.

68. Sarah Wolfensohn and Maggie Lloyd, Handbook of Laboratory Animal Management and Welfare (Oxford: Blackwell, 2003), 8 (Wolfensohn and Lloyd 2003).

69. French, Antivivisection and Medical Science, 112-158; M.A. Finn and J.F. Stark, 'Medical science and the Cruelty to Animals Act 1876: a reexamination of anti-vivisectionism in provincial Britain', Studies in the History and Philosophy of Biology and Biomedical Science, 49 (2015), 12-23 (Finn and Stark 2015).

70. E.M. Tansey, “'The Queen has been dreadfully shocked:” Aspects of teaching experimental physiology using animals in Britain, 1876-1986', American Journal of Physiology, 274 (1998), S18-S33 (Tansey 1998).

71. G. Candy, 'The legal definition of cruelty in relation to the animal world', Animals Guardian, 1 (1890), 5 (Candy 1890).

72. Quoted in Vyvyan, In Pity, 87.

73. Finn and Stark, 'Medical science' (2015).

74. Wellcome Library, London (hereinafter Well) SA/RDS A3; 'Do they ever say “no”?' (editorial), Animals' Defender, March 1954, 46.

75. Cobbe tried and failed to prosecute David Ferrier in 1881.

76. F.L.O. Morris, The Curse of Cruelty. A Sermon [on Ps. Xxxvi. 6] Preached in York Minster (London, England: Elliot Stock, 1886), 80 (Morris 1886).

77. Anon., Animals Guardian, 2 (1891/1892), 33.

78. Vyvyan, In Pity, 28, 77-78.

79. Amongst other tortures, Bernard employed an 'apparatus for determining the effects of heat upon live animals'. He wrote: 'The animals exhibit a series of symptoms always the same and characteristic. At first the creature is a little agitated. Soon the respiration and circulation are quickened. The animal opens its mouth and breathes hard. Soon it becomes impossible to count its pantings; at last it falls into convulsions, and dies generally uttering a cry': Frances Power Cobbe, Light in Dark Places (London: VSS, n.d.), 20.

80. 'Our programme', Animals Guardian, 1, (1890), 2; G. Candy, 'Should the vivisection act of 1876 be repealed?', Animals Guardian, 1 
(1891), 49-50; “Plain truth” past and present', Animals Guardian, 2 (1891/1892), 6-9 (Candy 1890, 1891).

81. Chien-hui Li, 'Mobilizing literature in the animal defense movement in Britain, 1870-1918', Concentric: Literary and Cultural Studies 32.1 (2006), 27-55 (Li 2006).

82. Charles Darwin, Times, 23 June 1876: Darwin Correspondence Project, Letter no. 10,546, viewed 12 July 2016, http://www.darwinproject. ac.uk/DCP-LETT-10546 (Darwin 1876).

83. Samuel L. MacGregor-Mathers, 'The roots of cruelty', Animals Guardian, 1 (1890), 27 (MacGregor-Mathers 1890).

84. 'Hyrtl, prof. of anatomy, Vienna, on vivisection as demonstration to students', Zoophilist, 1 (1881/1882), 145 (Hyrtl 1881/1882).

85. Glaholt, 'Vivisection as war'; editorial, Zoophilist, 1 (1881/1882), 190 (Glaholt 1881/1882).

86. Anon., Zoophilist, 1 (1881/1882), 244; 'Items of interest', Animals Guardian, 1 (1890), 34-35 (Anon 1881/1882, 1890).

87. Lewis Carroll, 'Some popular fallacies about vivisection', Fortnightly Review, 23 (1875), 847-854 (Carroll 1875).

88. 'Two views of the vivisector', Zoophilist, 1 (1881/1882), 194.

89. Times, 25 April 1881, 10.

90. Lady Burdon Sanderson, Sir John Burdon-Sanderson: A Memoir (Oxford: Clarendon Press, 1911), 157; Parliamentary Papers, 41 (1876), Q5482 (Sanderson 1876).

91. Quoted in Boddice, 'Species of Compassion'.

\section{References}

Anon. (1833). Five reasons against cruelty to animals. Animals' Friend, 1, 14. Anon. (1881/1882). Zoophilist, 1, 244.

Anon. (1890). Items of interest. Animals Guardian, 1, 34-35.

Bates, A. W. (2008). Indecent and demoralising representations: Public anatomy museums in mid-Victorian England. Medical History, 52, 1-22.

Bates, A. W. (2010). The anatomy of Robert Knox: Murder, mad science and medical regulation in nineteenth-century Edinburgh. Brighton: Sussex Academic Press.

Bates, A. W. (2014). Vivisection, virtue ethics, and the law in nineteenthcentury Britain. Journal of Animal Ethics, 4, 30-44. 
Boddice, R. (2007). A history of attitudes and behaviours toward animals in eighteenth- and nineteenth-century Britain: Anthropocentrism and the emergence of animals. Lampeter: Mellen.

Bills to Prevent Cruelty to Animals. (1826). Parliamentary History and Review, 756-775.

Candy, G. (1890). The legal definition of cruelty in relation to the animal world. Animals Guardian, 1, 5.

Candy, G. (1891). Should the vivisection act of 1876 be repealed? Animals Guardian, 1, 49-50.

Candy, G. (1891/1892). "Plain truth" past and present. Animals Guardian, 2, 6-9.

Carpenter, W. B. (1882). The ethics of vivisection. Fortnightly Review, 31, 237-246.

Carroll, L. (1875). Some popular fallacies about vivisection. Fortnightly Review, 23, 847-854.

Chaplin, S. (2008). The heroic anatomist: Dissection and the stoic ideal. Retrieved from http://www.rcpe.ac.uk/library/listen.

Chippendale, J. (1839). Experiments on animals. Lancet, 1, 357-358.

Christianity and its Effect Upon Man's Treatment of Animals Considered. (1839). Church of England Magazine, 6, 294-296.

Darwin, C. (1871). The descent of man and selection in relation to sex. London: John Murray.

Darwin, C. (1876, June 23). Darwin correspondence project. Times, Letter no. 10,546. Retrieved July 12, 2016, from http://www.darwinproject.ac.uk/ DCP-LETT-10546.

Drummond, J. L. (1838/1839). On humanity. London Medical Gazette, 24, 160-163.

Drummond, W. H. (1838). The rights of animals, and man's obligation to treat them with humanity. London: John Mardon

Elston, M. A. (1987). Women and antivivisection in Victorian England, 1870-1900. In N. A. Rupke (Ed.), Vivisection in historical perspective (pp. 259-273). London: Croom Helm.

Etherington, G. (1842). Vivisection investigated and vindicated. Edinburgh: P. Richard.

Finn, M. A., \& Stark, J. F. (2015). Medical science and the cruelty to animals act 1876: A re-examination of anti-vivisectionism in provincial Britain. Studies in the History and Philosophy of Biology and Biomedical Science, 49, $12-23$. 
French, R. D. (1975). Antivivisection and medical science in Victorian society. Princeton, NJ: Princeton University Press.

Glaholt. (1881/1882). Vivisection as war; editorial. Zoophilist, 1, 190.

Glaholt, H. R. (2012). Vivisection as war: The "Moral Diseases" of animal experimentation and slavery in British Victorian Quaker pacifist ethics. Society and Animals, 20, 154-172.

Gompertz, L. (1992). Moral inquiries on the situation of man and brutes... Fontwell: Centaur Press.

Guerrini, A. (2008). Animal experiments and antivivisection debates in the 1820s. In C. Knellwolf, \& J. Goodall (Eds.), Frankenstein's science: Experimentation and discovery in romantic culture, 1780-1830 (pp. 71-86). Aldershot: Ashgate.

Hall, M. (1828). On the mechanism of the act of vomiting. Lancet, 2, 600-602.

Hall, M. (1831). A critical and experimental essay on the circulation of the blood. London: R.B. Seeley \& W. Burnside.

Hull, R. (1842/1843). On vivisection. London Medical Gazette, 32, 864.

Hughes, G., \& Lawson, C. (2011). RSPCA and the criminology of social control. Crime, Law and Social Change, 55, 375-389.

Hunt, L. (1841). Essays (pp. 47-48). London: Edward Moxon.

Hyrtl. (1881/1882). Prof. of anatomy, Vienna, on vivisection as demonstration to students. Zoophilist, 1, 145.

Kean, H. (1995). The "smooth, cool men of science:" The feminist and socialist response to vivisection. History Workshop Journal, 40, 16-38.

Kean, H. (1998). Animal rights: Social and political change since 1800. London: Reaktion.

Knox, R. (1839). Some observations on the structure and physiology of the eye and its appendages. Lancet, 1, 248-251.

Knox of Edinburgh. (1844). Medical Times, 10, 245-246.

Lallemand, F. (1825). Observations pathologiques propres à éclairer plusieurs points de physiologie (review). London Medical and Physical Journal, 53, 238-245

Lansbury, C. (1985). The old brown dog: Women, workers, and vivisection in Edwardian England. Madison, WI: University of Wisconsin Press.

Li, C. H. (2006). Mobilizing literature in the animal defense movement in Britain, 1870-1918. Concentric: Literary and Cultural Studies, 32(1), 27-55. Linzey, A. (2009). The link between animal abuse and human violence. Brighton: Sussex Academic Press. 
Lordat, J. (1854). Mental dynamics in relation to the science of medicine. Journal of Psychological Medicine and Mental Pathology, 7, 252-263.

MacGregor-Mathers, S. L. (1890). The roots of cruelty. Animals Guardian, 1, 27.

Maehle, A. H. (2014). The ethics of experimenting on animal subjects. In R. B. Baker \& L. B. McCullough (Eds.), The Cambridge world history of medical ethics (pp. 552-557). Cambridge: Cambridge University Press.

Magendie, F. (1824). An elementary compendium of physiology; for the use of students (E. Milligan, Trans.). Philadelphia, PA: James Webster.

Manuel, D. E. (1990). Marshall Hall (1790-1857): Vivisection and the development of experimental physiology. In N. A. Rupke (Ed.), Vivisection in historical perspective (pp. 78-104). London: Rutledge.

Marx, K. F. H. (1846). The moral aspects of medical life (J. Mackness, Trans.). London: John Churchill.

Miller, I. (2009). Necessary torture? Vivisection, suffragette force-feeding, and responses to scientific medicine in Britain c. 1870-1920. Journal of the History of Medicine and Allied Sciences, 64, 333-372.

Morris, F. O. (1886). The curse of cruelty. A sermon [on Ps. xxxvi. 6] preached in York Minster. London: Elliot Stock.

Mushet, D. (1839). The wrongs of the animal world. London: Hatchard and Son.

Niven, C. D. (1967). History of the humane movement. London: Johnson Publications.

Olmsted, J. M. D. (1944). François magendie. New York: Schuman.

Percival, T. (1803). Medical ethics, or a code of institutions and precepts adapted to the professional conduct of physicians and surgeons. Manchester: S. Russell.

Phillips, M. T., \& Sechzer, J. A. (1989). Animal research and ethical conflict: An analysis of the scientific literature: 1966-1986 (p. 7). New York: Springer.

Regan, T., \& Singer, P. (Eds.). (1989). Animal rights and human obligations. Englewood Cliffs, NJ: Prentice-Hall.

Sanderson L. B. (1911). Sir John Burdon-Sanderson: A Memoir. Oxford: Clarendon Press.

Shaw, G. B. (1934). Prefaces (p. 257). London: Constable.

Society for preventing cruelty to animals. (1825, June). Morning Chronicle, 3.

SPCA. (1832). Sixth Report and Proceedings. London: W. Molineux.

Stammers, T. (2013). The NHS-No place for conscience. Catholic Medical Quarterly, 63, 12-14.

Steintrager, J. A. (2004). Cruel delight: Enlightenment culture and the inhuman. Bloomington, IN: Indiana University Press. 
Stevenson, L. G. (1956). Religious elements in the background of the British anti-vivisection movement. Yale Journal of Biology and Medicine, 29, 125-157. Tansey, E. M. (1998). The queen has been dreadfully shocked: Aspects of teaching experimental physiology using animals in Britain, 1876-1986. American Journal of Physiology, 274, S18-33.

Wolfensohn, S., \& Lloyd, M. (2003). Handbook of laboratory animal management and welfare. Oxford: Blackwell.

Wynter, A. (1863). Subtle brains and lissom fingers: Being some of the chisel-marks of our industrial and scientific progress, and other papers (p. 66). London: Robert Hardwicke.

Open Access This chapter is licensed under the terms of the Creative Commons Attribution 4.0 International License (http://creativecommons.org/licenses/by/4.0/), which permits use, sharing, adaptation, distribution and reproduction in any medium or format, as long as you give appropriate credit to the original author(s) and the source, provide a link to the Creative Commons license and indicate if changes were made.

The images or other third party material in this chapter are included in the chapter's Creative Commons license, unless indicated otherwise in a credit line to the material. If material is not included in the chapter's Creative Commons license and your intended use is not permitted by statutory regulation or exceeds the permitted use, you will need to obtain permission directly from the copyright holder.

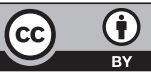

